\title{
THE ARAB SPRING AND THE INVOLVEMENT OF EXTERNAL ACTORS IN DEMOCRATIZATION PROCESSES
}

DOI: $10.17450 / 150214$

Stefania Negri

Università degli Studi di Salerno

\section{The 'Arab Spring' as the latest stage of the global democratic revolution?}

In 2011, more than two decades after the momentous events that swept across Eastern Europe, a massive popular revolution against authoritarian regimes, ignited by the protests erupted in Tunisia in December 2010, put down roots throughout the Middle East and North Africa - from Egypt, Libya, Algeria and Morocco to Syria, Yemen, Bahrain and Jordan - and brought democratization processes back under the spotlight of the international community.

This major movement towards democracy in the Arab world, known as the Arab Spring', marked a new wave ${ }^{1}$ of popular quest for pro-democratic changes in State governance that revitalized the "global democratic revolution", heralded at the beginning of the Nineties as the "the most profound event of the twentieth century and,

\footnotetext{
1. According to contemporaneous politological studies, the 'Arab Spring' is part of a fourth wave of democratization belonging to the $21^{\text {st }}$ century, the third being the one affecting Central and Eastern Europe in the Nineties, the second dating back to the aftermath of World War II, the first concerning democratic processes occurred between the $18^{\text {th }}$ and the $20^{\text {th }}$ century (reported in Gustavo Gozzi, Umano, non umano. Intervento umanitario, colonialismo, "primavere arabe", il Mulino, Bologna, 2015, p. 252, fn. 16).
} 
in all likelihood, the fulcrum on which the future development of global society will turn."

In his book Umano, non umano. Intervento umanitario, colonialismo, 'primavere arabe, ${ }^{3}$ Gustavo Gozzi thoroughly examines this region-wide phenomenon and provides the reader with an accurate account of the events occurred in some of the countries affected by the 'Arab Spring', while offering a critical assessment of the underlying historical, religious, and socio-political causes as well as a prospective evaluation of its legacy.

As Gozzi aptly stresses, the 'Arab Spring' defeated the argument that the Muslim world is not suited for democracy ${ }^{4}$ and proved to be a genuine bottom-up popular revolt driven by a profound democratic impulse. Rather than reacting to external pressure, the young Arab protesters were simply determined to take their future in their own hands speaking the language of democracy and human rights. The international community immediately responded in the same lexicon and offered its financial and even military assistance in support of these efforts towards democratization. Such an assistance, however, was not free from criticism, given that Western States had for a long time shown political support to the three toppled leaders - Ben Ali, Mubarak and Gaddafi - justifying this support with security interests and the fight against terrorism - an attitude that contributed to the survival of totalitarian regimes and to decades of frustrating stasis in the region.

The international response to the 'Arab Spring', especially the involvement of Western countries and the United Nations - an aspect that is also touched upon in Gozzi's broader analysis - triggers some considerations on the role played by external actors in national democratic transitions and its possible justifications under international law.

\section{The United Nations' role in support of democracy and democrati- zation processes ${ }^{5}$}

Several international actors - including international organizations, States, NGOs, and the civil society - have deeply contributed to the spread of democracy around the

2. T.M. Franck, “The Emerging Right to Democratic Governance”, in American Journal of International Law, 86, 1992, pp. 46-91, p. 49.

3. G. Gozzi, Umano, non umano, fn.1.

4. Ibid., p. 252.

5. See the first landmark document “An Agenda for Democratization”, issued by Secretary-General Boutros-Ghali in 1996. 
world as non-party actors in national democratization processes. Building on the assumption that democracy is ultimately a means to achieve international peace and security, ${ }^{6}$ economic and social progress and development, as well as respect for human rights - the three pillars of the UN mission as set forth in the Charter - the UN has played over time a pivotal role in supporting and strengthening democracy worldwide.

The contribution of the Organization to democracy and its assistance in democratic transitions has mainly developed through both normative and operational activities.

The UN has long advocated a concept of democracy that is holistic, encompassing the procedural and the substantive, formal institutions and informal processes, majorities and minorities, men and women, governments and civil society, the political and the economic. Its normative contribution has thus been focused on the definition of principles, norms and standards that constitute the basis of democracy and help to better define its legal and conceptual foundations. ${ }^{7}$

The evolution of these norms and standards has been matched by an ever greater operational activity carried out on the field by UN entities. During decades of engagement in democratization, the UN has been confronted with the triple challenge of building or restoring democracies, preserving democracies, and improving the quality of democracies. ${ }^{8}$ It has been especially engaged in promoting democratic governance in emerging and transitional democracies through sustained support to democratic institutions, support to civil society, facilitation of constitution-making, promotion of human rights, the rule of law and access to justice, strengthening of legislation and media capacities, electoral assistance and long-term support for electoral management bodies, and promotion of women's participation in political and public life.

Within this broad framework, technical assistance to electoral processes, in particular, is considered the core of UN support because it makes possible the exercise of the right to self-determination of peoples as envisaged in the UN Charter. It is now

6. In line with this approach is Gozzi's argument that a strong support to democratic movements in the Arab world is the ultimate solution to achieve, in the long period, a political solution to the destabilization of the Middle East (G. Gozzi, Umano, non umano, p. 243).

7. UN institutions have mainly defined its legal content from a human rights perspective, identifying the basic elements of democracy in the respect for human rights and fundamental freedoms, access to power and its exercise in accordance with the rule of law, participation in the conduct of public affairs, directly or through freely chosen representatives, the holding of genuine, periodic, free and fair elections by universal suffrage and by secret ballot, a pluralistic system of political parties and organizations, the separation of powers, the independence of the judiciary, transparency and accountability in public administration, and free, independent and pluralistic media. See Commission on Human Rights resolution 2002/46, "Further measures to promote and consolidate democracy", 23 April 2002; Human Rights Council resolution 19/36, "Human rights, democracy and the rule of law", 23 March 2012; General Assembly resolution 69/178, "Promotion of a democratic and equitable international order", 18 December 2014.

8. See Report of the United Nations High Commissioner for Human Rights, "Study on common challenges facing States in their efforts to secure democracy and the rule of law from a human rights perspective", 17 December 2012. 
common opinion that as democracy has spread, so has the role of elections as means to establish legitimate governments, in accordance with the principle enshrined in the Universal Declaration of Human Rights that the will of the people, as expressed through periodic and genuine elections, is the basis of government authority.

In line with this view, the UN has always considered support to credible and inclusive elections as a cornerstone of democracy, while stressing that it provides electoral assistance only upon request of the interested parties, respectful of the principles of state sovereignty and national ownership of elections. In order to appraise the extent of its engagement, suffice it to say that over the last 20 years the Organization has helped more than 110 Member States and/or territories, and that such an assistance has been considered as a crucial and successful component in peace-keeping, peace-building and in establishing and deepening democratic governance. In 2011 alone, the United Nations Development Programme, the world's largest provider of democratic assistance, helped more than 130 countries and devoted US \$1.5 billion in resources to democratic governance. Among the countries where technical assistance was offered throughout the whole electoral process were also those involved in the 'Arab Spring', where the deployment of UN missions and observers contributed to the holding of the first democratic elections taking place after decades of authoritarianism. ${ }^{9}$

Whether UN involvement in democratization processes is completely neutral and free from ideological and political bias is hard to say, especially in light of the strategic role it plays in key democracy-building activities, and also in consideration of its declared mission in favour of the development of a culture of democracy through the gradual embedding of democratic principles into the broader social fabric. ${ }^{10}$ It is however indicative that the Organization has always emphasized that it has neither sought to export or promote any particular national or regional model of democracy, nor advocated for a specific model of government, but that it has instead promoted democratic governance as a set of values and principles that should be followed for greater participation, equality, security and human development. ${ }^{11}$ The UN has in fact been very keen to stress that it provides technical support in an impartial way and that democracy is

\footnotetext{
9. See G. Gozzi, Umano, non umano, especially p. 239.

10. According to the UN, "education for democracy" is a broad concept which can help to inculcate democratic values and principles in a society, encouraging citizens to be informed of their rights and the existing laws and policies designed to protect them, as well as training individuals to become democratic leaders in their societies. See General Assembly resolution 69/268, "Education for Democracy", 5 March 2015.

11. See General Assembly resolution 66/285, 3 July 2012, the latest of a series of resolutions entitled "Support by the United Nations system of the efforts of Governments to promote and consolidate new or restored democracies."
} 
ultimately a political process in the ownership of each country. It has usually defined itself as "an impartial and independent actor that stands for inclusiveness, pluralism and tolerance." 12

\section{Military interventions in support of democracy}

During the 'Arab Spring' it became evident that Qaddafi's regime in Libya not only denied democracy, human rights, and self-determination to the people of Libya, but also engaged in murderous armed attacks against sections of the Libyan civilian population that constituted war crimes and crimes against humanity. In fact, as Gozzi reports in his book, this scenario led to the UN Security Council's referral of the situation to the Prosecutor of the International Criminal Court and the adoption of resolution 1973 (2011) pursuant to Chapter VII of the UN Charter. ${ }^{13}$ In this resolution, determining that the situation continued to constitute a threat to international peace and security, the Security Council demanded that the Libyan authorities comply with their obligations under international law, including international humanitarian law, human rights and refugee law, called for an immediate cease-fire and enforcement of the embargo on arms, established a no-fly zone and imposed a ban on flights, and most important, authorized Member States, acting nationally or through regional organizations or arrangements, "to take all necessary measures" to protect civilians and civilian populated areas under threat of attack. As it is well known, this authorization opened up the door to the use of military force by a multi-state coalition, which later covered also the subsequent need to support regime change at the request of the Libyan National Transitional Council when it gained recognition as the legitimate representative of the Libyan people.

Not unexpectedly, this Western-led military intervention, although 'legitimized' by the UN, immediately became the object of harsh criticism by those who cried out against contemporary forms of colonialism. From a legal perspective, it revitalized the intense scholarly debate over the controversial nature and legal justification of humanitarian and pro-democratic interventions - a discussion that had reached its apex in the mid-Nineties, following the unprecedented resolution adopted by the Security Council

12. "Guidance Note on Democracy", issued by Secretary-General Ban Ki-moon in 2009, para. IV.

13. Security Council resolution 1970, adopted unanimously on 26 February 2011, and resolution 1973, adopted on 17 March 2011. See G. Gozzi, Umano, non umano, pp. 258-261. 
with regard to the crisis in Haiti, when the first military intervention was authorized in order to put an end to the violent overthrowing of the democratically elected president Aristide. $^{14}$

\section{The 'Arab Spring' viewed through the lens of international law}

The 'Arab Spring' has triggered opposite reactions and stimulated a wealth of critical comments, inter alia, on the power and limits of mass revolt, the challenge of turning popular protest and anger into real and lasting change, the power of the media and the risks posed by postmodern imperialism. But beyond sociological and politological insights, this phenomenon has also stimulated some fresh considerations on the legal status of democracy under international law and the alleged existence of a right to democratic governance 25 years after the fall of the Berlin wall.

Such reflections, which are key in determining whether the involvement of external actors in the democratization of the Arab world was justified under international law, focus on a few crucial questions. Has democracy gradually evolved from moral prescription to an overarching international law principle requiring democratic legitimacy of governments? Is there an international legal obligation imposing democratic governance, that is enforceable through the use of force? Has a human right to democratic governance finally emerged?

The answer is obviously complex and scholars are deeply divided. Moreover, it has to be noted that the literature has grown exponentially in the last two decades in response to the seminal article of 1992 by the late Thomas Franck, where he argued that a right to democratic governance was emerging in international law, that "democracy [was] beginning to be seen as the sine qua non for validating governance", ${ }^{15}$ and that democratic governance was becoming an enforceable entitlement (though through collective, not unilateral, action).

Recent contributions have explored international practice to assess the present legal status of democratic entitlement and have concluded that Franck's right to democratic governance must continue to be regarded as emergent in general international

14. Security Council resolution 940, adopted on 31 July 1994. See, for example, S. Negri, "L'intervento delle Nazioni Unite nella crisi haitiana e il principio di legittimità democratica nell'ordinamento internazionale", in P. Picone (ed.), Interventi delle Nazioni Unite e diritto internazionale, Cedam, Padova, 1995, pp. 337-405.

15. T. Franck, "The Emerging Right to Democratic Governance”, p. 46. 
law, while a right to democracy has been established as a regional norm in Europe. ${ }^{16}$ As a consequence, while it is almost common-place to say, after the UN, that democracy is considered a "core value of general interest in the international community" and that it has become over time a standard required for the recognition of States and for admission to membership in international organizations, it is indeed harder to argue that democratic governance is today a recognized requirement for the legitimacy of governments and that it has evolved into a settled democratic norm imposing a legal obligation on States. Nor is it possible to state that it can be enforced through military intervention in the absence of a legitimizing $\mathrm{UN}$ resolution, ${ }^{17}$ safe in the case of permissible military assistance to a people fighting for self-determination, provided that there is their free will and an explicit request for external help to overthrow an oppressive government. But even so, it is not a shared opinion that the right to internal self-determination equates with a right to democracy.

Needless to say, the subject remains highly controversial...

16. See especially G. Fox, "Democracy, Right to, International Protection”, in Max Planck Encyclopaedia of Public International Law, opil.ouplaw.com; S. Marks, "What has Become of the Emerging Right to Democratic Governance?", in European Journal of International Law, 22, 2011, pp. 507-524.

17. Even so, it has to be noted that the practice of the Security Council subsequent to the Haitian case shows that it has been rather reluctant to authorize other military interventions to reinstall an overthrown government, the only relevant case being Sierra Leone. See C. Vandewoude, "The Democratic Entitlement and Pro-Democratic Interventions: Twenty Years after Haiti?”, in Anuario Mexicano de Derecho Internacional, 12, 2012, pp. 779-798, p. 786. 